\title{
How to Respect the Religious Quasi-Other? Methodological Considerations in Studying the Kimbanguist Doctrine of Incarnation
}

\author{
Mika Vähäkangas
}

This chapter outlines a methodology for theologically analyzing and assessing predominantly oral non-Western theologies. First, the two major existing approaches are deliberated upon, namely, the (cultural/social) anthropology of Christianity and ecumenical (systematic) theology. ${ }^{1}$ After exploring the pros and cons of both, a brief background of the Kimbanguist Church is presented, which serves as the case for reflecting upon methodological considerations. This is followed by an attempt to integrate the useful elements of both anthropology and theology. The whole exercise is conducted with the ecumenical theological agenda in mind, and therefore does not propose any value judgment on theological and anthropological or ethnographical approaches as such.

The Kimbanguist doctrine of incarnation is used as the concrete material for methodological deliberations because of its critical situation at the moment of writing - the Kimbanguist Church is very close to becoming the first church ever to have its membership in the World Council of Churches (wCC) discontinued on doctrinal grounds. Furthermore, it is a leading African Instituted Church with a rich oral theological tradition and deep involvement in the Kongo cultural heritage.

\section{We Need New Approaches in the Theological Study of World Christianities}

I stand in the green and white garmented crowd in the square formed by the residence of the head of the Kimbanguist Church (chef spirituel), Simon Kimbangu's mausoleum, the huge temple, and a couple of other buildings, in

1 Ecumenics is the activity of promoting unity between Christian churches. Ecumenical theology is an academic discipline which studies ecumenics on the one hand and churches on the other, with the aim of providing analyses for the use of the stakeholders in ecumenics. Systematic theology is a discipline that deals with the doctrinal and philosophical aspects of theology. In this chapter, ecumenical theology is approached as a systematic theological discipline thereby ignoring, e.g., its historical dimension, which comes close to church history. 
the holy city of Nkamba, the New Jerusalem, in the Lower Congo. The crowd chants meditatively, "Ozali Nzambe, ozali Nzambe," (you are God) and if I have earlier had doubts about how to interpret these kinds of expressions of Kimbanguist piety, it now seems clear that the words are addressed to Simon Kimbangu Kiangani, the head of the church. However, the exact implication of these words and their interpretation in terms of the official Kimbanguist position remains unclear to me. ${ }^{2}$

There is plenty that is very familiar to any Christian in the life and worship of the Kimbanguists: the Lord's Prayer, Trinitarian formulations, frequent use of the Bible, and so forth. Additionally, Kimbanguist theology subscribes to all major Christian doctrines like the Trinity, the incarnation of the Logos in Jesus of Nazareth, and Jesus' atoning death, thus creating a salient starting point for a researcher, such as myself, with a systematic theological background. ${ }^{3}$ However, the familiar always comes with a twist of particularly Kimbanguist interpretation and there is none of the feeling of being located between two worlds, Africa and the West, so common in many mainline and Pentecostal African churches. Kimbanguism belongs strongly to the Congolese world. Thus, religiously, the Kimbanguists are not really "us" from the point of view of mainline Protestantism but neither can they be properly counted as the "other." Therefore, I regard them, as well as many other African Instituted Churches with their own strong theological emphases, as "quasi-other," belonging either in- or outside Christianity depending on the observer and the criteria used. ${ }^{5}$ At the same time, from the cultural point of view, the Kimbanguist Church is very deeply rooted in the Congolese soil, meaning that the Hellenic-Western way of theologizing is not the most natural. ${ }^{6}$ In the majority of the historic Christian churches, the early so-called ecumenical (that is, general or common to all)

2 Field workdiary Nkamba 9th July 2015, 3. Additionally, when believers from Eastern Congo asked the chef spirituel to end the war in the region, this impression was further strengthened.

3 See Le catéchisme kimbanguiste (Châtenay-Malabry, France: Éditions Entraide Kimbanguiste, 2003).

4 Kimbanguists themselves typically describe Congolese Christianity as threefold: Catholic, Protestant, and Kimbanguist, thus distancing themselves from Protestantism. Joseph Mangoyo, La relecture du kimbanguisme: A travers les définitions (Brazzaville: Département de la Presse et Information, 2009), $88 \$ 674$. See, for instance, Joseph Diangienda Kuntima, L'histoire du kimbanguisme. Editions Kimbanguistes: Châteney-Malabry, 2003, 282. This view was adopted de facto by Mobutu's government in 1971. Susan Asch, L'Église du Prophète Kimbangu: De ses origines à son rôle actuel au Zä̈re. (Paris: Karthala, 1983), 101.

5 On the porousness of borders of Christianity, see Mika Vähäkangas, "Mission Studies, Syncretism and the Limits of Christianity during the Time of the Heretical Imperative," Swedish Missiological Themes 98, 1 (2010): 12-13.

6 I interpret the statements that Kimbanguism is rather faith than theology (e.g. Mangoyo, $L a$ relecture du kimbanguisme, $42 \S 299,43 \S 307,107 \S 826,109 \S 844$ ) as pointing to this, academic 
councils of especially Nicaea (A.D. 325), Constantinople (A.D. 381), and Chalcedon (A.D. 451) became normative. In them, the core Christian teachings like the Incarnation and Trinity were authoritatively formulated with the help of Greek language and philosophy. The council positions were naturally not accepted by all - they were summoned because there were differing opinions and in each case some of the minority opinion ended outside of the newly formulated doctrinal orthodoxy.

The Kimbanguist Church was admitted to the wCC in 1969 after a thorough scrutiny that included plenty of doctrinal consideration. Membership in the WCC has been and still is very important for Kimbanguists both in terms of identity and theology. ${ }^{7}$ Today, due to the increasingly clear differences between the Kimbanguist doctrine of incarnation and the positions generally held in the wCC member churches, the Kimbanguists' position in the organization has become precarious. ${ }^{8}$ The doctrine of incarnation can be considered the cornerstone of Christianity; without a doctrine that considers Jesus of Nazareth as the God incarnate, Christianity may not have developed separately from Judaism, and there would not have been any need to develop specifically Christian doctrines like the Trinity which attempts to weld monotheism together with the idea of incarnation. Thus there is an ongoing discussion whether the Kimbanguists should be allowed to continue in the WCC on doctrinal grounds. ${ }^{9}$ Whatever the fate of the Kimbanguist Church in the wCC, one may hope that the deliberations of both parties - the Kimbanguists and those who want to expel them from the WCC - will be built on functioning communication.

In ecumenical systematic theological debates one tends to rely very strongly on written documentation even if much of the discussion happens orally; any meaningful result should usually be reflected in writing, too. This dialogue also begins from the premise that one has common ground from which to begin the construction of consensus: values, doctrines, and the Bible. Traditionally, the mode of such interdenominational disputes (later referred to as dialogues)

theology having been introduced to the church largely through ecumenical contacts. See also Diangienda Kuntima L'histoire du kimbanguisme, 256-257.

7 See Asch, L'Église, 56, 62-68; Diangienda Kuntima, L'histoire du kimbanguisme, 311 and his description about the WCC application process, 207-211 and Broggi's interpretation of the same process, Joshua D. Broggi, Diversity in the Structure of Christian Reasoning: Interpretation, Disagreement, and World Christianity (Leiden: Brill, 2015), 67-70.

8 Broggi, Diversity, 25-26. As a part of the process, a Swiss theologian, Dr. Martin, was sent by the wCc for a fact-finding trip. She eventually became Kimbanguist and wrote a well-known general introduction to Kimbanguism. Marie-Louise Martin, Kirche ohne Weisse: Simon Kimbangu und seine Millionenkirche in Kongo (Basel: Reinhardt, 1971).

9 E-mail from Daniel Buda to the author, 2016-06-14. 
was that one attempted to convince the other party of one's position. This approach has, however, been challenged by receptive ecumenism in which the starting-point lies in learning from the other party. ${ }^{10}$

However, in both cases, the starting point is the common ground. In the traditional approach, a critical challenge towards the discussion partner represented a way of recognizing the partner as more or less equal in the dialogue even if one considered one's own position somewhat superior. During the time of colonialism, when encountering "pagans," only a few missionaries would bother to engage them in dialogue, thereby excluding them. In receptive ecumenism the equality between the partners is even more pronounced. In systematic theological debates proposing a challenge or critique can thus be seen as a form of inclusion through recognizing common ground, and also as an expression of equality. This inclusion presupposes, however, a common language and a common conceptual universe. This does not self-evidently seem to be the case with the Kimbanguists and the rest of the players in the ecumenical movement. Theological vocabulary, albeit similar in appearance, would not necessarily be similarly understood in the Kimbanguist and HellenicWestern theologies. Therefore, the usefulness of the traditional, or even the receptive, ecumenical approach is questionable, as the potential common ground looks like quicksand. ${ }^{11}$

The role of judgment in ecumenical systematic theological debates as described above is based on a normative approach where each of the participants in the debate considers the tradition (s)he represents as the most convincing and thereby most true. Were it not so, the person would, logicallyspeaking, change her or his affiliation. Yet the normative critical position easily leads to a prejudiced approach where the discussion partner that does not share the same vocabulary as "we" (in the sense of the community of the analyst) is directly labeled as heterodox even before understanding what $\mathrm{s} / \mathrm{he}$ is attempting to express. A classic example of this is the Western labeling of Oriental churches as monophysitic, a position that was held for many centuries and has only recently been rectified through careful analysis of, for example, the Ethiopian Tewhado Church theology. ${ }^{12}$ Even though a totally unbiased

10 Paul D. Murray, Receptive Ecumenism and the Call to Catholic Learning: Exploring a Way for Contemporary Ecumenism (Oxford: Oxford University Press, 2008).

11 For more on this see Mika Vähäkangas, "Interreligious and Interchurch Debates: Open Questions for the 21st Century," in Den Blick weiten: Wenn Ökumene den Religionen begegnet: Tagungsbericht der 17. Wissenschaftlichen Konsultation der Societas Oecumenica, eds. Andrew Pierce and Oliver Schuegraf (Leipzig: Evangelische Verlagsanstalt, 2014), 51-67.

12 See Aielé Tekle-Haymanot, La dottrina della chiesa etiopica dissidente sull'unione ipostati$c a$ (Pont. Roma: Institutum Orientalium Studiorum, 1956). 
approach is not possible, having judgment as both the starting-point and the result runs a high risk of failing to understand the studied theology on its own premises. Thus, traditionally, systematic theology tends to be a very ethnocentric enterprise where one's own position - in academic studies usually Western mainline Christian - is the yardstick of true Christianity, that is, the truth. This is less than helpful in encountering (potential) Christianities whose common ground with Western traditions is debatable and even at best an object of careful analysis.

Another alternative in ecumenical theology is to approach the normative role or judgment in a system immanent manner. This means that the researcher does her or his best to enter the thought world of the other that is being studied. In that case, critical analysis arises from the premises of the studied theological system. Is it internally coherent? Does it perform what it promises? This system immanent approach is a much more fruitful starting point when dealing with the quasi-other. However, due to the fact that theologians generally have exercised this within the confines of the Hellenic-Western thought patterns, the outcome is not necessarily much more understanding vis-à-vis churches of the majority world. Nonetheless, this approach facilitates the postponement of theological judgment or criticism proposed in this chapter.

While systematic theology builds the notion of inclusion and equality on mutually challenging dialogue, and criticism on the basis of common ground, classical anthropological approaches to inclusion and equality have traditionally built on difference. Unlike systematic theology, anthropology usually builds primarily on unwritten sources. The credo of anthropology could be said to be radical openness to the other, meaning that researchers are willing to try and understand even such cultural phenomena as are unintelligible or even unacceptable in their home cultures. The task of the anthropologist is to interpret those phenomena and make them understandable in Western academia, in the sense of explaining both their background and meaning. ${ }^{13}$ As a result, challenge and criticism do not ideally belong in the anthropological toolkit. However, because analysis and theorizing are part of the Western academic sphere, this results in a divided or double reality. In the field, the researcher attempts to be radically open, sharing the everyday life of the community studied. However, when a good part of the anthropological exercise deals with creating theoretical insights about being human in our cultures and social settings, it is natural that this dimension of the anthropological endeavor cannot be inclusive in relation to most of the communities studied. The academic world where this part of the process takes place is beyond the reach of

13 See Joel Robbins' chapter in this book. 
the communities studied, both linguistically and culturally, and oftentimes also physically. From the theologian's perspective, there is also a danger that an abyss may open up between the studied culture and the resulting theorizing that takes place in the academic world. Thus, while there is a high degree of openness and relative equality during anthropological fieldwork, this cannot cover the whole research process. From the ecumenical studies point of view this looks as if, during fieldwork, one acts as if there is openness and equality, while in terms of results, these values may yield to the power of Western Enlightenment epistemology and plausibility patterns that reign supreme in the Western academia, in spite of many anthropologists' brave attempts to subvert them. ${ }^{14}$ While anthropological radical openness is an asset in gaining understanding of deeply rooted Kimbanguist ritual and thinking, it lacks the means to make that understanding meet with the ecumenical partners' theologies and is thus not inclusive enough for ecumenical theological purposes. It needs to be noted that the anthropological toolkit may well be quite sufficient for anthropologists whose agenda is different from that of ecumenical theologians.

Arising from the ecumenical situation, there is a need to consider how best to approach the Kimbanguist doctrine of incarnation (i.e., that Simon Kimbangu, his sons, and the present chef spirituel, his grandson, are divine incarnations) in order to facilitate a meaningful and equal dialogue between the Kimbanguists and their ecumenical partners. The aim of this chapter is, therefore, to develop a methodology for studying the Kimbanguist doctrine of incarnation that would render results facilitating meaningful ecumenical theological dialogue between confessional boundaries, a goal of ecumenical theology. This is best achieved through combining anthropological and ecumenical theological insights by postponement of theological judgment, thereby creating a two-step process. First, Kimbanguist theology is approached with the radical openness gleaned from anthropology, with theological analysis and discernment following thereafter. Kimbanguist theological partners are involved in both steps. In the process of attempting to understand and interpret Kimbanguist doctrine, Kimbanguist theologians, both formally trained and laypersons, ${ }^{15}$ play an active part in exposing the content of their faith and in serving as discussion partners in assessing the validity of my interpretation of

14 On varying plausibility patterns see Peter Berger and Thomas Luckmann, The Social Construction of Reality: A Treatise in the Sociology of Knowledge (London: Penguin Books, 1991), 110-121.

15 Here, a theologian is understood to be any person who attempts to formulate his or her faith in a consistent and critical manner irrespective of whether (s)he has received any formal theological training. Any reflective believer can thus be counted as a theologian, 
their faith. This interpretation is a form of intercultural translation process with the aim of making the Kimbanguist doctrine, embedded as it is in Kongo culture, also intelligible to outsiders. In the second step, the interpretation of Kimbanguist doctrine is exposed to theological scrutiny in the sense of comparing it to major doctrinal trends in Catholicism, Protestantism, and Orthodoxy. The results of this scrutiny will become a part of theological dialogue between Kimbanguist and other theologians, with the Kimbanguists being invited to comment, correct misjudged conclusions, and defend their position vis-à-vis competing interpretations of Christian faith. The theological scrutiny will not need to be normative in the sense of uttering a verdict on whether Kimbanguist doctrine is right or wrong, or true or false. Those kinds of utterances rather belong to faith communities like churches or the wCc. The task of academic ecumenical theology is only to provide well analyzed theological data, not to draw the doctrinal borders of Christianity.

It needs to be noted that, in the first step, the means of data collection is not the same as in anthropology in spite of the methodological option for radical openness because its aim is to facilitate later theological deliberations. Thus, the focus of what is recorded and observed is different, as is the selection of the informants.

In this chapter, the theological content of the doctrine is touched upon only to the extent it contributes to the development of the methodological agenda. This paper contains methodological considerations belonging to a project on Kimbanguist theology of incarnation. The data of the project consists of published and unpublished Kimbanguist theological texts, participant observation in small Kimbanguist diaspora communities over a decade, as well as fieldwork in Nkamba/Nouveau Jérusalem and Kinshasa in July 2015.

\section{Simon Kimbangu and His Church}

Simon Kimbangu (born ca. 1889), a former Baptist catechete, began to heal, preach, and prophesy early in 1921, drawing multitudes to his little village of Nkamba in Lower Congo. The Belgian colonial authorities arrested him about six months after the beginning of his ministry and sentenced him to death for high treason, in spite of his not having been involved in politics or armed uprising. Due to international protest, the death sentence was transmuted to life imprisonment. He died in 1951, having spent most of his sentence in a

whereas formal theological education does not necessarily make someone into a theologian even if it contributes to the development of critical theological thought. 
solitary cell. The Kimbanguist movement was fiercely persecuted, but the exile of Kimbangu's followers caused it to spread to new parts of Belgian Congo. The Kimbanguist Church was registered in 1959, right before Congolese independence. ${ }^{16}$

The doctrine of the emerging movement was not codified, and there were many views of it, especially with regards the role and nature of Simon Kimbangu. ${ }^{17}$ Gradually, however, the movement began to take form as a church in spite of the harsh repression by the colonial authorities. The formulation of official Kimbanguist teachings began with the first Kimbanguist Catechism of 1957 as their expression. In the beginning, Simon Kimbangu was officially considered to be a prophet, this also being reflected in the name of the church, "L'Église de Jésus Christ sur la terre par le prophète Simon Kimbangu." Yet since the very beginning, popular belief has had the tendency to see Simon Kimbangu as more than a prophet and, with the change in church leadership from Simon Kimbangu's first to his second son, there was a gradual development in the church's public position towards seeing Simon Kimbangu as the incarnation of the Holy Spirit. The Catechism of 1957 referred to Kimbangu as the Consoler that Jesus had promised (Jn 14: 12-18) but it was clearly stated that he was not God (§19). ${ }^{18}$ Nonetheless, teaching about the incarnation of the Holy Spirit in Simon Kimbangu eventually became the teaching of the church, although it was not included in the 1971 version of the Catechism, or in the 2003 version, which is basically a reprint of three earlier doctrinal documents, the 1971 Catechism being one of them. Today, the Kimbanguist teaching of incarnation has expanded into considering the three sons of Simon Kimbangu as incarnations of the three persons of the Trinity, and the present chef spirituel as the reincarnation (métempsychose) of Simon Kimbangu, and therefore the continuation

16 On Simon Kimbangu and history of the Kimbanguist Church see, for instance, Werner Ustorf, Afrikanische Initiative: Das aktive Leiden des Propheten Simon Kimbangu (Bern: Herbert Lang, 1975); Broggi, Diversity, 27-56; Martin, Die Kirche ohne Weisse; Asch, L'Église; Diangienda Kuntima, L'histoire du kimbanguisme.

17 Martin, Die Kirche, 235. Diangienda Kuntima, L'histoire du kimbanguisme, 172-174 claims that the doctrine was clear from the time of Simon Kimbangu. However, as he describes, the organization of the church was only carried out from 1957 when the persecutions were gradually ceasing, meaning that there was no possibility of formalizing the teaching as doctrine in the absence of church structures.

18 Le catéchisme kimbanguiste 1957 §1 \& §2: «R: Tata Simon KIMBANGU est l'Envoyé de notre Seigneur Jésus-Christ. Q: Comment savons-nous que Tata Simon KIMBANGU est l'Envoyé de notre Seigneur Jésus-Christ? R: Jésus-Christ lui-même nous a promis de demander à son Père de nous envoyer un autre Consolateur pour réaliser plus que lui. Lisez Jean 14: 12-18.» 
of the incarnation of the Holy Spirit. ${ }^{19}$ This is in spite of the fact that, due to not having formulated a new Catechism since 1971, these teachings have not been formally codified in writing. They can, however, partly be found in the church's official website (that is, at the moment, under reconstruction) and in the ritual life of the church even at its very center, Nkamba. Additionally, these doctrinal topics are dealt with both in writing and in interviews by the leading Kimbanguist theologians, while theological teachers opposing this development were expelled from the Lutendele Kimbanguist theological seminary on the outskirts of Kinshasa - which is today the theological faculty of the church - this leading to a temporary shutdown of the seminar. ${ }^{20}$

\section{$3 \quad$ Some Tools for Analysis}

According to Wyatt MacGaffey, the Bakongo live in two different worlds simultaneously: the customary, Kikongo-speaking oral, and the bureaucratic, francophone written. ${ }^{21}$ This observation will serve as an analytical cornerstone in the construction of methodological tools to tackle Kimbanguist theology.

The bureaucratic, francophone reality was imported by the colonialists and is a typical Western cultural product. It builds on an Enlightenment scientific worldview and regards the world as manageable through bureaucratic systems. Its rigid logic has developed out of a quite mechanistic understanding of both natural and social realities. Being basically a European construct, this realm communicates easily with Western academic culture. It is also the first layer of Congolese reality that an outside observer encounters and tends to be

19 See Aurélien Mokoko Gampiot, Kimbanguism: An African Understanding of the Bible (University Park PA: Pennsylvania University Press, 2017), 122-154. Broggi, Diversity, 63-67, 71-80.

20 Fieldwork diary Nkamba 9th July 2015, 3. See also Mokoko Gampiot, Kimbanguism, 148.150. An example of such theologizing that became unacceptable: Léon Nguapitshi Kayongo, "Aspects and Problems of Present Day Kimbanguism in a Historical Perspective," Africa Theological Journal 26, no.1 (2003): 88-101; Léon Nguapitshi Kayongo, "Aspects and Problems of Present Day Kimbanguism in a Historical Perspective, Part 2," Africa Theological Journal 27, no. 1 (2004): 50-58. Thus also Broggi, Diversity, 81.

21 Wyatt MacGaffey, "Kimbanguism \& the Question of Syncretism in Zaïre," in Religion in Africa: Experience \& Expression, ed. Thomas D. Blakely et al. (London: James Currey, 1994), 247-248. Compare to the three realms in Tanzanian Christian life worlds in Päivi Hasu, Desire and death: History through ritual practice in Kilimanjaro. Transactions of the Finnish Anthropological Society (Helsinki: Finnish Anthropological Society, 1999), 41-42, 231-237, 241-245, 359-361; Mika Vähäkangas, "Babu wa Loliondo - Healing the tensions between Tanzanian worlds," Journal of Religion in Africa 45, 1 (2015), 23-27. 
predominantly written. In the Kimbanguist Church, one often reads the Bible in French but the rest of ritual life takes place mostly in Kikongo or Lingala.

When the language changes from French to Kikongo (or Lingala, too, in the case of the Kimbanguist Church), and the preferred form of communication from written to oral, the whole surrounding cultural world also changes. Kikongo and Lingala are only seldom used for written communication beyond short instructions, pamphlets, or the like. Thus, Kikongo customary reality can mostly be captured in observation and discussions. The cultural plausibility patterns are also profoundly different depending on which sphere one operates in. The way of managing the world in customary terms is no longer predominantly by bureaucratic means but by spiritual power because that world is not interpreted primarily in scientific but in spiritual terms.

Another set of analytical tools needed for the development of methodology are the partly overlapping concepts of folk belief, theology, and doctrine. Here, I use folk belief in the sense of a popular faith content that has not been systematically elaborated and not discussed and approved by a church hierarchy. Most commonly, folk belief is not expressed in written form. Meanwhile, the word theology will be used to denote a non-academic ecclesiastic activity - a critical, self-critical, and systematic elaboration of faith content - and not the academic discipline as such. ${ }^{22}$ The task of theology is to make the faith content intelligible and acceptable in the given context. Here, doctrine refers to the theologically expressed faith content of a church, which has been accepted as the correct interpretation of faith, and which serves as the yardstick of heresy and orthodoxy.

The borders of these three are not water-tight. To think theologically, one does not need theological education, and a lay church member's religious thought can well be defined as theology if it contains a critical approach which attempts to see the larger picture of reality and to argue in a credible and intelligible manner. Meanwhile, an academic degree in theology is no guarantee that the educated person's religious thinking would qualify as theology. In most churches, doctrine is very clearly defined. Procedures for approving something as doctrine often exist, and doctrine plays a normative role in terms of defining who is right and who is wrong in theology. Yet there is always a dimension of interpretation in doctrine, meaning that the seemingly clear-cut difference between theological opinions and arguments on the one hand, and theology and doctrine on the other, is not quite so sharp.

22 However, in contexts where faculties of theology are run by churches, as is the case in the DRC, the border between ecclesial and academic theology is very porous. Here the emphasis is on ecclesial theology because I am interested in the formation of doctrine and not in academic debates as such. 
In the case of the Kimbanguist Church, the borders between these three categories are particularly porous. Folk belief involves considerable argumentation and numerous attempts to express the Kimbanguist faith in an intelligible and acceptable manner to outsiders, due to the fact that the Kimbanguists tend to be regarded with a high level of suspicion by other Christians; a Kimbanguist believer is constantly on the defense. However, much Kimbanguist oral argumentation (usually taking place in Kikongo or other vernaculars) does not follow the Enlightenment scientific modes of proving one's case but, rather, operates in the customary Kikongo world and argues for the credibility of the Kimbanguist position by reference to miracles or other proofs of spiritual power. Although such argumentation does not necessarily coincide with academic and bureaucratic, francophone reality, I would count some of it as theology in the ecclesial sense inasmuch as it enters into rational argumentation about Kimbanguist faith despite its being framed in the Kongo customary plausibility patterns. This means that in order to qualify as theology, thinking does not need to share the Hellenic-Western theological thought world or Enlightenment plausibility patterns but rather be a systematically, critically, and self-critically argued exposition of the faith content in any cultural sphere. Consequently, not all the written material in French would necessarily fulfill the criteria for being counted as theology due to its lack of critical and selfcritical dimensions.

From the point of view of this study, the fact that the Kimbanguist Church predominantly operates orally poses a major challenge in defining its doctrine. If one were to use a minimalistic definition of doctrine as something that is officially and formally adopted by the church in a written form, only the Catechisms, definitely products of the bureaucratic French cultural sphere, would pass as doctrinal statements of the Kimbanguist Church. They shed only a dim light on the Kimbanguist faith, however; furthermore, the fact that the contracts of some Lutendele teachers were discontinued due to their opposition to church teachings that were not in the Catechisms shows that oral forms of doctrine may be normative. Therefore, I need to loosen the definition of doctrine to cover theological positions that are considered normative by the church leadership, no matter whether they are written or oral. Admittedly, this move leaves a large grey zone in which it is not clear whether an idea is a commonly held theological position or doctrine. However, I hope to be able to argue below that this result reflects the Kimbanguist theological and doctrinal scene better than producing clear-cut images that are fantasy. ${ }^{23}$ 
As noted above, the systematic theological approach tends to engage the partner in critical dialogue whereas an anthropologist tends to minimize her role in the collection of data. It would be quite possible to base theological analysis purely on observation and very open-ended interviews. That would, however, be extremely inefficient time management and also leave a lot of loose ends in argumentation. Additionally, the theological and philosophical quality of the data would probably not be flattering to the Kimbanguist intelligentsia. It is not always the case that you find the sharpest theological minds exactly where you expect to find them. Let us look more closely at the different types of data in this project and the ways of gathering them.

Approaching theology and doctrine in a foreign cultural context is a demanding exercise both in terms of cultural knowledge and research ethics. The possibility of a meaningful theological dialogue presupposes a common ground and a common language, as pointed out above. If the researcher does not know enough about the culture, and especially about the underlying plausibility patterns and logic, it is difficult to create meaningful theological dialogue. In this project's approach, the hypothesis is that every human being is rational and attempts to explain the world to herself in a coherent and logical manner, even though the result might not look like that through the parameters of another culture. Following from this, to label another culture's ideas as gibberish or superstition generally points more to a basic lack of understanding of the culture on the part of the external interpreter than to the nature of the ideas in their culture of origin. Something is gibberish only if it does not make sense in its cultural setting - in the case of the Kimbanguists either the customary Kikongo or the bureaucratic French sphere. This conviction is, of course, very much in line with cultural anthropology whereas academic theology traditionally has tended to be more normatively bound to Hellenisticbased argumentation.

From an ethical point of view, a researcher should always be in search of the truth, no matter whether one believes in the possibility of finding it or not. On the one hand, the search for truth presupposes that, when one thinks one has found it, one will stick to it and argue for it as convincingly as one can. On the other hand, the search also presupposes openness towards change rather than dogmatically clinging to what one holds to be true at a certain time. So, one could maintain that while theology traditionally has emphasized the first point, anthropology's ethical emphasis has presented the second. In data collection, the anthropological position is a better solution. 
Ethnographic methods are very good at collecting data on folk beliefs through participatory observation, informal discussions, and semi-structured interviews. In this case, the researcher would naturally focus on cosmological issues, rituals, and the like. When it comes to oral theological and even doctrinal data, however, the situation becomes complicated. How is one to decide where best to find a person capable of theological argumentation? Snowballing is probably the best way forward when sketching theological argumentation while, in terms of doctrine, hints from the church hierarchy would be beneficial. An interviewee who has failed to answer theological questions to his own satisfaction is generally willing to point out someone else whom he considers more able to deal with the matter. Kenyan philosopher Odera Oruka, when developing his philosophy of sagacity in cooperation with traditional sages in the villages, relied on the villagers' opinions in choosing his discussion partners but judged for himself the philosophical quality of his partners. ${ }^{24}$ In a like manner, when studying oral theology, snowballing will probably lead you both to persons of great and lesser theological abilities.

As with Odera Oruka's discussions leading to a philosophy of sagacity, theological discussions aiming to gather oral theology challenge the partner to formulate ideas as clearly and succinctly as possible and to explore further the consequences of the chosen arguments. Thus, what would traditionally be called an interviewer is here rather a discussion partner or even sometimes a sort of a devil's advocate who challenges the informant to venture further in argumentation. For many a researcher in the social sciences, this kind of approach would be completely unacceptable because here the researcher is consciously influencing the thought and argumentation of the informant. Yet the very same researchers would usually agree that their manner of interviewing also affects the interviewees. Thus here, instead of attempting to minimize the impact of the interviewer, the researcher discussion partner intentionally directs the discussion in a manner that it produces wider and more profound theological vistas. In this scenario, one needs to be careful not to put words in the partner's mouth but rather to tease out genuine, new theological argumentation.

It is commonly agreed that the researcher always has an influence on the research data due to methodological, topical, and practical choices and, in the case of personal contact, also due to his personality. One may wonder, however, whether this kind of dialogical approach, one which consciously aims at a

24 For the philosophy of sagacity see Odera Oruka, Sage Philosophy (Leiden: Brill, 199o). 
mutual development of ideas that will change the thinking of both partners, is methodologically sound.

Each research methodology needs to be formulated with the research question and discipline in mind. Thus, what would be sufficient for anthropology may not be so for ecumenics, and what is needed in ecumenics may not be acceptable in anthropology. Ecumenics as a discipline studies ecumenical endeavors and relations between different Christian churches and groups. Even if the goal of ecumenics as a discipline per se is not Christian unity, it tends to reflect the ideal of ecumenics as ecclesial practice, namely improved relations between Christian churches and groups. In a larger view, this goal could also be extended to interreligious relations. In the study of Kimbanguist doctrine, ecclesial ecumenical interest provides the motivating ground for the choice of the research theme, coupled with the fact that the Kimbanguist Church is practically and theoretically a landmark case in the ecumenical movement because no church has ever been rejected from the World Council of Churches once it has been accepted as a member.

In this case, it becomes evident that the goals of understanding the world and changing the world are interwoven. The aim of understanding and interpreting the Kimbanguist doctrine is not only of purely academic interest but also a contribution to the ecumenical debate. At best, this kind of research can provide both parties, the Kimbanguist Church and those churches that are disappointed with its doctrinal developments, a more detailed and balanced picture of the ecumenical situation. Moreover, the WCC will have a more solid basis for judgment and hopefully a deeper understanding of pluralism in Christianity and the processes leading to it. For Kimbanguists, teasing out theological argumentation would equip them to explain and defend their cause.

My role as a researcher becomes crucial here. It is evident that I am not a member of the church studied but, rather, have a relation to the wCC that could be described as one of critical solidarity. My relation to the Kimbanguist Church began as a keen interest in the story of Papa Simon Kimbangu, motivated by my curiosity about African theologies and my Pan-African leanings. Eventually, returning to the Nordic region after service in Tanzania, I came in contact with some small Kimbanguist communities and finally traveled to Nkamba with Swedish Kimbanguists over a decade later. Thus, while having strong sympathy for the partly Congolese nationalist and Pan-Africanist Kimbanguist political agenda, as a child of the Enlightenment I have no way of subscribing to the Kimbanguist religious agenda. In theology, therefore, my goal is to understand and interpret the Kimbanguist doctrine in order to 
facilitate meaningful communication between the Kimbanguist and Enlightenment rationalist worlds.

Theology in its philosophical or systematic form is a very logocentric exercise. Therefore, in spite of the issues discussed above, it should not be overly difficult to perceive how an interview can serve as a source of analysis for theology. When one moves over to ritual, where the verbal dimension may play varying roles, the question of whether and how to analyze ritual as a theological source becomes more pointed.

The gap between systematic theological logocentrism and ritual cannot simply be glossed over by resorting to the patristic dictum "lex orandi, lex credendi" ("the law of praying is the law of believing"). While it is clear that one needs to see the connection between ritual life and faith content, there is a danger of interpreting this maxim as only referring to the verbal dimensions of ritual. However, the action accompanying the words is what gives them the meaning in ritual. Thus, for example, in spite of the words of institution being the same in the Roman Catholic Eucharist and the Reformed Lord's Table, the way the sacrament is conducted reveals a difference in meaning. "This is my body," is interpreted through transubstantiation in the Catholic, and as metaphorical in the Reformed setting. Additionally, the variation in ritual action reflects the difference in understanding. Thus, the underlying cosmology, the words of the ritual, and its non-verbal acts together comprise an interaction that formulates the meaning of the ritual. The non-verbal action can serve as a key to open the cosmology or theology behind the words.

In addition to ritual action's serving as a helpful tool in interpreting the verbal dimension of the ritual, there are actions that are not accompanied by words or, perhaps, bound to any fixed wordings. In such cases, can those actions be seen as independent sources of theological analysis? Here the question arises of how to theologically analyze the non-verbal. Likewise, in the case of ritual accompanied by a set wording, one may wonder whether some of the ritual's meaning is lost if the non-verbal dimensions are used only to interpret the verbal.

The first obvious requirement of any proper analysis of ritual action is that it needs to be contextual. Thus, for example, the fact that everyone kneels in front of the chef spirituel does not directly point to his divine status as the Holy Spirit's incarnation. While one always kneels in the Kimbanguist Church 
when praying, one also kneels in front of highly respected persons who are not perceived as divine according to the church doctrine. Thus, when meeting with the chef spirituel's brother, one kneels even if it became clear in the "bana 26 " controversy that not all Simon Kimbangu's offspring should be perceived as God's incarnations. ${ }^{25}$ In the Kimbanguist context, not kneeling definitely conveys the message that one does not consider someone divine, yet kneeling does not necessarily point to divine status. This is so also because in the traditional Kongo context, kneeling was a common way of expressing submission in front of a superior.

The second requirement is that the interpretation needs to take the larger ritual picture into account. For example, all Kimbanguist services are concluded with nsinsani, a collect. In it, women and men usually compete against each other over who raises more funds. Seen separately, this could be interpreted as an expression of gender segregation but a wider view immediately erases such an idea. Often, the genders do not sit on separate sides of the church, women can be pastors, and while there are, for example, women's associations, most of the associations are open to both genders. Thus, the resulting analysis would need to be nuanced to take into account that whereas genders are not seen as the same or perhaps not even similar yet they are somehow equal.

\section{$6 \quad$ How to Turn the Non-written into Theology?}

Once the written, oral, and observational data have been collected, their varying natures as well as differences in their content pose challenges to analysis.

In theological analysis, or close reading, one has traditionally started from the premises that the written data tend to provide a correct representation of the intended meaning of the author in the sense that the author has had the opportunity to ponder what he is writing and to return to the text to edit it. There is also a certain epistemological optimism about the possibility of interpersonal communication. Yet even here, one should not overlook the hermeneutical problems involved in the interpretation of texts. These problems increase in relation to cultural, historical, and contextual differences. I will not deal with questions related to textual interpretation here, however, but

25 On the "bana 26" controversy see Armand Apota Salimba Monga Lisomba, Histoire de la dissidence au sein de l'Église Kimbanguiste à la lumière de 26=1: Témoignage. (Kinshasa, 2013). On kneeling in front of the chef spirituel's brother see fieldwork diary Kinshasa $5^{\text {th }}$ July $2015,3-5$. 
concentrate on the other types of sources. ${ }^{26}$ When the cultural gap is significant, it is imperative to postpone theological judgment even after this close reading in order to gain the fullest possible picture of the studied theology before assessing it.

In interviews, the interviewee generally does not have the opportunity of unlimited time to ponder his answer. In some kinds of research this can be a benefit, especially if attempting to record views that are not only rationally reasoned but also related to emotions and subconscious values. Generally, this is not an aim for theological interviews. However, orality allows for flexibilities that written text does not as readily do. No one speaks using perfect formal grammar, and in speaking one is less bound by its rules which creates space for a wider variety of expression. The non-verbal dimensions of the interview also give hints as to a proper interpretation of the verbal. Likewise, especially in multilingual contexts, it is more natural to blend words or even sentences of different languages. This is not only a way of gaining more freedom of expression but also a clue to the researcher about the linguistic universes where theological thought takes place. As mentioned above, in the case of the Bakongo, the French and Kikongo linguistic universes are quite separate and, among the Kimbanguists, the mélange of vocabularies can reveal quite a bit about what is going on in Kimbanguist theologies.

One way of avoiding somewhat thoughtless theological responses in interviews is to conduct them in focus groups. There, if an idea is unclearly or even erroneously expressed, the peers will correct it. Additionally, the group members will challenge each other to take the argumentation further, thereby facilitating the task of the researcher. The ideas developed in focus groups can also be considered as more representative of the community as they are not only a matter of an outsider challenging a single theologian.

If interviews are a type of source that is created in cooperation between the interviewees and the researcher, in observation the role of the researcher is even greater as it is generally not possible to pose questions clarifying whether an observation is correct, while in interviews it is. One can naturally ask members of the community afterwards about the meaning of an observation but by that time the event has already passed and one can never return to it in exactly the same form. Furthermore, in observation there are usually countless things on which one could focus, while in an individual interview one can concentrate on the interviewee, his answers, and reactions. In a focus group, the situation is more complex and one needs to divide attention between the one

26 On how I see close reading of classics, see Mika Vähäkangas, "Modelling Contextualization in Theology," Swedish Missiological Themes 98, 3 (2010): 279-306. 
speaking and the reactions of the others. In observation, however, one is faced with a jungle of alternatives and no observation can cover more than a tiny section of the possibilities.

The researcher's creative role in the production of data in observation is not only limited to the more or less conscious choice of what he observes and what glides by unnoticed. The observation itself is molded by the cultural, theologi$\mathrm{cal}$, and personal conditions of the observer and the act of observing cannot be separated from interpretation of what is experienced. Such interpretation suffers from all the complexities of textual interpretation except that while one always can return to the original text (though not back to the first reading of it), one cannot return to the observed event. Additionally, while in the logocentric theological enterprise text - whether written or spoken - is both the (preferred) source and the mode of work, observation is not a text. Although textualized in a fieldwork diary or a description of the event, it is then no longer the observation and even less the event, but rather a doubly distanced (first as an observation which is at the same time an interpretation and secondly as a textualized product of the observation) artifact based on the event.

In being textualized, the resulting artifact has entered the textual realm where theological close reading takes place. Yet it is not the type of text that one would conventionally use in theological analysis and, additionally, analyzing it would lead to a kind of auto-analysis in which the analyzer is at the same time a partial producer of the text. The observations can thus only be used to reconstruct concepts or dimensions of cosmologies by concentrating on the memories or recordings of original verbal and non-verbal expressions. Only seldom can observation bring additional clarity to argumentation or the logic behind the argumentation - that needs to be gleaned from texts and interviews.

\section{Analyzing between the Worlds}

In this last section, I present what theological analysis of the Kimbanguist doctrine of incarnation might look like, based on texts, interviews, and observation. In this, there is a specific problem with the historical dimension. Written texts, mostly in French, date back about half a century whereas interviews and observation are possible only in present time. Naturally, some of my observations were made a decade earlier but, because my knowledge of Kimbanguist theology, among other abilities, has evolved during this time, I have to treat the different layers of my observation with great care. Thus, I must have missed many theological nuances, yet I have not been able to check from discussions 
of that time whether I did so due to researching from behind a veil of ignorance. ${ }^{27}$ Another dimension is that what you know, and can be seen to know, influences the manner in which the people disclose issues to you. Thus, basically, I have no trustworthy access to earlier non-textual sources. Access to earlier good quality research would only partly alleviate the problem because the interpretational dimensions of observation are usually not very transparent. ${ }^{28}$

In addition to banking on earlier research, one way of dealing with the lacuna of earlier non-written data is to conduct such a close reading that it tackles the non-written reality behind the texts. This resembles the social historical approaches to biblical texts. Statements and arguments in the texts do not arise from nowhere but are reactions or responses to events, thoughts, and trends in the community creating those texts. Thus, for example, the first Kimbanguist Catechism's clear statement that Simon Kimbangu is not God must be read against the assumption that there must have been people - most probably in the Kimbanguist Church - attributing divine status to Simon Kimbangu. ${ }^{29}$ Otherwise the statement would make no sense. When there is no direct textual evidence of this, it means that these ideas were expressed orally. As the language of the texts is predominantly French and one can expect that earlier oral communication would have taken place in vernaculars, it seems that the ideas of incarnation extending to Simon Kimbangu and his offspring were only expressed orally in vernaculars. This would be very much in line with MacGaffey's theory of the two Kongo life spheres.

Thus, when the Kimbanguist Church was officially founded and registered in 1959, the official written doctrine in French began to take form, one which dealt primarily with questions about Kimbangu, leaving the classical Protestant theological questions aside. ${ }^{30}$ Eventually, following ferocious accusations of syncretism, classical Protestant theological issues were introduced, pointing

27 In my view, John Rawls' "veil of ignorance" (John Rawls, A Theory of Justice, revised edition (Cambridge, MA: Belknap Press, 1999)) describes a researcher's position in an apt way, even if Rawls used the term in a very different manner. Research process leads one towards increased knowledge of the phenomenon studied, and each step of interpretation opens up further interpretational possibilities. As a result, one is steadily behind a veil that covers what is not known, and if one knew today what one will know tomorrow, one's interpretation would be different. And because observation is a process of interpretation from the very beginning, observation would also be very different.

28 Of course, some dimensions of my interpretation are subconscious and therefore even my own observations are not fully transparent to me.

29 Le catéchisme kimbanguiste 1957 §19: «Q: Pourquoi le nom de Tata Simon KIMBANGU estil mis en avant, est-ce que Tata Simon KIMBANGU serait Dieu? R: Non, Tata Simon KIMBANGU n'est pas Dieu... »

30 Asch, L'Église, 108. 
out that Kimbanguists actually subscribe to major mainline Christian doctrines, albeit sometimes with modifications. Obviously, there were many contextual Congolese dimensions, especially in the ethical code for the members. However, it seems probable from the church's texts and from Martin that the oral Kikongo and Lingala theology was not fully Protestant even during the Protestantization ${ }^{31}$ of the official teaching but, rather, that Simon Kimbangu's divine status, for example, was concurrently being proposed. According to Guy Bernard, the church was consciously playing a double game (Kimbangucentric and Christocentric) in order to balance between its two constituencies of those preferring the African and the Western approaches. ${ }^{32}$ It is impossible to judge in hindsight how popular such ideas were because contemporary observers had their agendas (just as any observers any time). Therefore, Martin would probably underestimate such tendencies because of her wish to integrate the Kimbanguist Church into the ecumenical movement. Martin was involved in the World Council of Churches' assessments of the Kimbanguist Church prior its acceptance, having been sent to Congo by the Moravian Church on a factfinding trip. ${ }^{33}$ The result of the process was that the Kimbanguist Church joined the WCC and Martin became the director of their theological institute. It would be in the interest of today's Kimbanguist establishment to consider the state of popular theology as quite the contrary in order to point out that the doctrine of Simon Kimbangu's and his sons' incarnation is not a new invention but has been believed by Kimbanguists from the very beginning. Perhaps the least engaged observer would be the American sociologist Susan Asch who estimated that only the very top hierarchy of the church as well as the theological institute students would have fully bought into the Protestantizing agenda. ${ }^{34}$

31 The first chef spirituel, Diangienda Kuntima, directed the church closer to Protestantism which led to tensions and splintering of the church. Gaston Mwene-Batende, "Le phénomène de dissidence des sectes religieuses d'inspiration kimbanguiste," Les cahiers $d u$ C.E.D.A.F. 6 (1971): 5. On the Protestantization of the church see Asch, L'Église, 113-128. Martin, Die Kirche, 203-204 shows her strong tendency to play down the heterodox elements found in the 1957 Catechism in order to pursue her theological agenda.

32 Guy Bernard, "La contestation et les Eglises nationales au Congo," Revue Canadienne des Etudes africaines 5, 2 (1971): 148.

33 Asch, L'Église, 120-122.

34 Ibid., 147. However, it is not clear how strictly she interpreted the Protestantizing agenda. She points out that almost all believers would believe that the chef spirituel had supernatural powers. This, as such, need not be seen as a major deviation from some, especially charismatic, Protestant movements. Later, she points out how in many Congolese regions, both members and pastors considered Simon Kimbangu as the Holy Spirit (148-179). 
Thus, when entering the wCc, the Kimbanguist Church was assessed in the same manner as all the other churches. It was the official written doctrine that counted. In this case it happened to be in French, thereby belonging in a life sphere quite different from that in which the church members lived fully or for the most part. Thus what was accepted in the wCC was the formal church which lived in a reality different from the members. ${ }^{35}$ Martin and probably also a number of other representatives of the formal church wished for the official doctrine to prevail. A move in that direction was the establishment of the Lutendele theological seminary outside Kinshasa (which later became the theological faculty of the Simon Kimbangu University). The seminary was supported with literature and teaching staff by the WCC and the Basel Mission (which later became Mission 21). ${ }^{36}$

Today, it is clear that the strategy to keep the Kimbanguist official doctrine close to mainline Protestantism has backfired, and instead of the Protestant French official doctrine turning into the daily oral lived doctrine of the believers, the opposite has been taking place. This process is not yet complete in the sense that there is not yet any Catechism overtly containing the doctrine of the Holy Spirit's incarnation in Simon Kimbangu. However, at the moment it seems that this teaching has become hegemonic, and it is difficult to hear it challenged from within the church. Additionally, the latest Catechism implies the incarnation of the Holy Spirit as Simon Kimbangu by referring to him as the consoler promised by Jesus, ${ }^{37}$ and by pointing out that "Papa Simon Kimbangu has existed with God since the beginning." 38

The analytical task, therefore, becomes one of analyzing how Kikongo and Lingala oral theology has transformed the Kimbanguist doctrine both in terms of process and content. It would appear that an analytical approach in the process would be to compare the oral and written theological sources. Wherever the oral theological sources are in line with the emerging trends in the written theologizing, it is a case of the customary Kikongo realm breaking into the bureaucratic, francophone one. Whenever the written theology is in variance with the lived theology, the difference can be used to shed light on the nature and content of these two spheres.

35 Asch, L'Église, 101-179 describes the difference dramatically as "le Kimbanguisme officiel" and "le Kimbanguisme des Kimbanguistes."

36 Ibid., 124-125; fieldwork diary Lutendele 17th July 2015.

37 Le catéchisme kimbanguiste 2003, 72 §2.

38 Le catéchisme kimbanguiste 2003, 72 §4: "Papa Simon Kimbangu a existé avec Dieu dés le commencement." 


\section{References}

Asch, Susan. L'Église du Prophète Kimbangu: De ses origines à son rôle actuel au Zä̈re. Paris: Karthala, 1983.

Berger, Peter and Thomas Luckmann. The Social Construction of Reality: A Treatise in the Sociology of Knowledge. Originally published in 1966. London: Penguin Books, 1991.

Bernard, Guy. "La contestation et les Eglises nationales au Congo." Revue Canadienne des Etudes africaines 5, no. 2 (1971): 145-156.

Broggi, Joshua D. Diversity in the Structure of Christian Reasoning: Interpretation, Disagreement, and World Christianity. Leiden: Brill, 2015.

Catéchisme de 1957 sur Simon Kimbangu en français (questions et réponses). Available in Joseph Mangoyo: Le catéchisme Kimbanguiste: Trois Catéchismes rassemblés dans un seul recueil. Brazzaville, 2014. (Electronic version.)

Le catéchisme kimbanguiste. Châtenay-Malabry, France: Éditions Entraide Kimbanguiste, 2003 .

Diangienda Kuntima, Joseph. L'histoire du kimbanguisme. Originally published in 1984. Editions Kimbanguistes: Châteney-Malabry, 2003.

Hasu, Päivi. Desire and Death: History through Ritual Practice in Kilimanjaro. Transactions of the Finnish Anthropological Society 42. Helsinki: Finnish Anthropological Society, 1999 .

Kayongo, Léon Nguapitshi. "Aspects and Problems of Present Day Kimbanguism in a Historical Perspective." Africa Theological Journal 26, no. 1 (2003): 88-101.

Kayongo, Léon Nguapitshi. "Aspects and Problems of Present Day Kimbanguism in a Historical Perspective, Part 2." Africa Theological Journal 27, no. 1 (2004): 50-58.

Lisomba, Armand Apota Salimba Monga. Histoire de la dissidence au sein de l'Église Kimbanguiste à la lumière de 26=1: Témoignage. Kinshasa, 2013.

MacGaffey, Wyatt. "Kimbanguism \& the Question of Syncretism in Zaïre." In Religion in Africa: Experience \& Expression, edited by Thomas D. Blakely et al., 240-256. London: James Currey, 1994.

Mangoyo, Joseph. La relecture du kimbanguisme: A travers les définitions. (electronic format.) Brazzaville: Département de la Presse et Information, 2009.

Martin, Marie-Louise. Die Kirche ohne Weisse. Basel: Friedrich Reinhardt Verlag, 1971.

Murray, Paul D. Receptive Ecumenism and the Call to Catholic Learning: Exploring a Way for Contemporary Ecumenism. Oxford: Oxford University Press, 2008.

Mwene-Batende, Gaston. "Le phénomène de dissidence des sectes religieuses d'inspiration kimbanguiste." Les cahiers du C.E.D.A.F. 6 (1971): 1-37.

Oruka, Odera. Sage Philosophy. Leiden: Brill, 1990.

Rawls, John. A Theory of Justice. Revised edition. Cambridge, MA: Belknap Press, 1999. 
Tekle-Haymanot, Aielé. La dottrina della chiesa etiopica dissidente sull'unione ipostatica. Pont. Roma: Institutum Orientalium Studiorum, $195^{6}$.

Ustorf, Werner. Afrikanische Initiative: Das aktive Leiden des Propheten Simon Kimbangu. Bern: Herbert Lang, 1975.

Vähäkangas, Mika. "Mission Studies, Syncretism and the Limits of Christianity during the Time of the Heretical Imperative." Swedish Missiological Themes 98, no. 1 (2010): $7^{-22 .}$

Vähäkangas, Mika. "Modelling Contextualization in Theology." Swedish Missiological Themes 98 no. 3 (2010): 279-306.

Vähäkangas, Mika. "Interreligious and Interchurch Debates: Open Questions for the 21st Century." In Den Blick weiten: Wenn Ökumene den Religionen begegnet: Tagungsbericht der 17. Wissenschaftlichen Konsultation der Societas Oecumenica, edited by Andrew Pierce \& Oliver Schuegraf, 51-67. Leipzig: Evangelische Verlagsanstalt, 2014.

Vähäkangas, Mika. "Babu wa Loliondo - Healing the tensions between Tanzanian worlds." Journal of Religion in Africa 45, no. 1 (2015): 1-34. 